\title{
Risk Taking in Venture Philanthropy: The Influence of Human Capital and Gender
}

Luisa Alemany, Mariarosa Scarlata and Andrew Zacharakis

Published Online: 29 Jul 2020 |https://doi.org/10.5465/AMBPP.2020.17899abstract

\section{Abstract}

Relying on human capital and gender role congruity theory, this paper seeks to identify the extent to which the top management team's human capital affects the risk-taking orientation of impact-focused investors. We then look at how gender moderates this relationship. We empirically ground our analysis in the context of venture philanthropy (VP) firms, a subset of the broader impact investing sector which is more hands-on and focused on funding social ventures. Relying on a combination of survey data to measure the VP firm's risk orientation, and biographical data to identify top managers' human capital, we find that neither commercial nor social human capital alone affect the risk orientation of VP investors. However, results show that gender, independently of the human capital, positively affects risk-taking when top managers are women. In the case of men, human capital plays a role. Contrary to expectations, teams with more men who have higher human capital garnered in a commercial endeavor have a lower risk-taking orientation while those with more human capital garnered in the social sector increases take higher risks. This suggests the existence of a gender bind dilemma in the social investment sector both for men and for women." 